\title{
Anti-Leukemic Potential of Methyl-Cobalamin Inactivation by Nitrous Oxide
}

\author{
J. Abels, A.C.M. Kroes, A.A.M. Ermens, J. van Kapel, M. Schoester, \\ L.J.M. Spijkers, and J. Lindemans \\ Institute of Hematology, Erasmus University, Rotterdam, The Netherlands
}

\begin{abstract}
Myelo-cytotoxicity of extended nitrous oxide $\left(\mathrm{N}_{2} \mathrm{O}\right)$ inhalation was described almost forty years ago and then incidentally applied already with temporary success for suppressing leukemia. In 1948 the accompanying megaloblastic maturation arrest was explained by inactivation of the methylcobalamin coenzyme and subsequent folate deficiency. We studied the anti-leukemic effect of $\mathrm{N}_{2} \mathrm{O}$ on a transplantable acute leukemia in $\mathrm{B}$ (rown) $\mathrm{N}$ (orway) rats. Progression of this $\mathrm{B}, \mathrm{N}, \mathrm{M}$ (yelocytic)L(eukemia) was measured as spleen and liver weights, and leukemic blood cell counts. The deoxyuridine (dU)-suppression test provided in vitro indication of the functional folate activity of leukemic cells. Breathing of $\mathrm{N}_{2} \mathrm{O}$-oxygen considerably reduced but did not eradicate, BNML-proliferation. Addition of anti-metabolites, interfering with some enzyme in the folate metabolism beyond the methylcobalamin co-enzyme dependent methionine synthase step, acted at least synergistically. The anti-leukemic effect of cycloleucine, which reduces S-adenosyl-methionine synthesis by inactivation of methionine adenosyltransferase, was moderate but became much stronger with $\mathrm{N}_{2} \mathrm{O}$ inhalation. Methotrexate, a potent anti-leukemic agent by inhibiting tetrahydrofolate (THF) generation through inactivation of di-HF reductase, became highly anti-BNML, even in low dosage when combined with or preceded by $\mathrm{N}_{2} \mathrm{O}$. 5-Fluorouracil, which inhibits methylene-THF dependent thymidilate synthase, itself was surprisingly anti-BNML, but also became much more potent with previous or concomittant $\mathrm{N}_{2} \mathrm{O}$ exposure. Preliminary dU-suppression test results with human acute leukemia cells, exposed to $\mathrm{N}_{2} \mathrm{O}$ and/or folate antagonists in vitro, correlated well with the in vivo BNML-experiments. Combining the anticobalamin activity of $\mathrm{N}_{2} \mathrm{O}$ with an anti-folate therefore seems to be a promising chemotherapeutic approach.
\end{abstract}

Key words: vitamin $B_{12}$, cobalamin, methylcobalamin, acute leukemia, leukemia, folates, anti-folates

Inhalation of nitrous oxide $\left(\mathrm{N}_{2} \mathrm{O}\right)$ has been known for almost two centuries to have an anesthetic effect [1]. It is still widely utilised as an adjuvant in present day anesthesiology. Regarded to be an inert and non-toxic gas for a long time, on the contrary it appeared to cause severe anemia when inhaled for 2 weeks or more by curareparalyzed patients with tetanus, who were tranquilized with $\mathrm{N}_{2} \mathrm{O}$ during artificial respiration [2]. This myelosuppressive effect of $\mathrm{N}_{2} \mathrm{O}$ inspired its opportunistic use in the treatment of hyperleukocytosis in two cases of both chronic myeloid leukemia [3] and childhood acute myeloid leukemia $|4|$ with spectacular, but short-term, remissions. Cytotoxicity of $\mathrm{N}_{2} \mathrm{O}$ has also been reported for cultured embryonal mouse cells [5], hematopoiesis in rodents [6], fibrosarcoma in mice [7], and Ehrlich ascites tumor [8]. This side effect of $\mathrm{N}_{2} \mathrm{O}$ became elucidated when its chemical reactivity with metal complexes, by which it induces the conversion of cob(I)alamin to cob(II)alamin, was discovered [9]. The clinical implication of this oxidative reaction with methylcobalamin was recognized 10 years later to be the cause of megaloblastic hematopoiesis occurring after long-term $\mathrm{N}_{2} \mathrm{O}$ anesthesia [10]. Deoxyuridine (dU) suppression tests on bone marrow cells megaloblastically transformed by $\mathrm{N}_{2} \mathrm{O}$ rendered the same results as on those in florid pernicious

Address reprint requests to Dr. J. Abels, Academic Hospital Dijkzigt, Dept. of Hematology, Dr. Molewaterplein 40, 3015 GD Rotterdam, The Netherlands. 


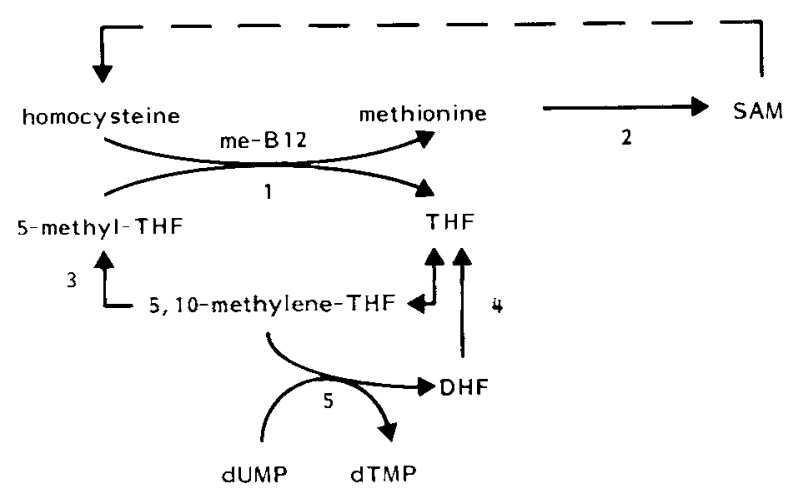

enzyme steps :

inhibited by :

1. methionine synthase

2. methionine adenosyltransferase

3. methylene-tetrahydrofolate reductase

4. dihydrofolate reductase

5. thymidylate synthase mia [23-31]. The test system, a transplantable leukemia, was originally provoked by benzanthracene in a Brown Norway (BN) rat [32] and called BNM(yeloid)L(eukemia). This BNML, resembling human acute promyelocytic leukemia [33], is transplanted by intraperitoneal injection with $10^{7}$ cells extracted from a leukemic spleen. Death ensues predictably 20-24 days later from thrombocytopenia, when proliferation of the leukemia has progressed to pronounced splenomegaly, hepatomegaly, and peripheral promyelocytosis. These parameters, which reliably reflect progression of the leukemia, were usually determined at the 19th or 20th day after inoculation. Under $\mathrm{N}_{2} \mathrm{O}$ treatment, consisting of exposition to a continuous flow of $50 \% \quad \mathrm{~N}_{2} \mathrm{O}-50 \% \mathrm{O}_{2}$ in a closed system, the rats remained awake and able to eat and drink sufficiently. $\mathrm{N}_{2} \mathrm{O}$ from day 8-18 after leukemia transplantation caused retardation of leukemic proliferation, as spleen and liver weights became $30 \%$ lower than in untreated animals, and blood promyelocytes were considerably reduced. Increase in plasma cobalamin, which runs parallel with leukemic expansion, regressed during $\mathrm{N}_{2} \mathrm{O}$ exposure, whereas plasma folate, which remains stable in leukemic rats, almost doubled during $\mathrm{N}_{2} \mathrm{O}$ exposure, probably reflecting methylfolate trapping. The dU-suppression test on leukemic spleen cells from $\mathrm{N}_{2} \mathrm{O}$ treated rats showed decrease of "de novo" thymidine synthesis in comparison with non-treated rats, compatible with methylcobalamin inactivation [34]. The overall results in BNML rats indicate that continuous breathing of $\mathrm{N}_{2} \mathrm{O}$ retards leukemic growth but does not eradicate the leukemic process $[23,28]$. Possible synergism of $\mathrm{N}_{2} \mathrm{O}$ with other folate antagonists, known to interfere with specific enzymatic steps in the folate metabolism (Fig. 1), was also explored. Cycloleucine in lower dosage is a fairly weak cytostatic agent, but in higher dosage develops limiting neurological and hematological toxicity [35-37]. It inhibits the methionine adenosyltransferase-dependent generation of S-adenosylmethionine (SAM), which is a basic substrate for vital methylation reactions, synthesis of polyamines, and endogenous formation of methionine. SAM also has been found to be an allosteric inhibitor of methylene-THF reductase. Lowering of SAM therefore will promote the trapping of methyl-THF, when demethylation has been blocked by $\mathrm{N}_{2} \mathrm{O}$. Cycloleucine, $50 \mathrm{mg} / \mathrm{kg}$ injected i.p. in BNMLrats at leukemia day 7 , reduced spleen and liver weights at day 20 to almost the same degree as did continuous inhalation of $\mathrm{N}_{2} \mathrm{O}$ from day 7 to 19. Combination of the two treatments was clearly synergistic as evidenced by further lowering of liver and spleen weights, and by a drop in peripheral leukemic cell counts. dU-suppression tests on leukemic spleen cells 24 hours after injecting cycloleucine and/or starting $\mathrm{N}_{2} \mathrm{O}$ inhalation showed little change after separate exposures but considerably more in motherapeutic potential of $\mathrm{N}_{2} \mathrm{O}$, alone or in combinatio with other anti-folates, in an experimental acute leuke- 
combination. It made no difference if cycloleucine was injected or added in vitro to spleen cells from $\mathrm{N}_{2} \mathrm{O}$ treated leukemic rats [24].

Methotrexate (MTX), the inhibitor of di-hydrofolate (DHF) reductase, which is crucial for the maintenance of intracellular THF pools, has since long been widely applied in the treatment of acute leukemias, lymphomas, and solid tumors [38]. Its dose-limiting toxicity has more recently been combatted with so-called folinic acid (leukovorin) rescue, a MTX antidote, after high-dose MTX. Synergism between $\mathrm{N}_{2} \mathrm{O}$ and MTX has been suggested to be the explanation for unexpected toxicity of adjuvant chemotherapy containing MTX, shortly after anesthesia with $\mathrm{N}_{2} \mathrm{O}$ during surgery for breast carcinoma [39]. In BNML rats, sacrificed on the 20th day of leukemia, 2 $\mathrm{mg} / \mathrm{kg}$ MTX i.p. on day 10 , was less effective than $\mathrm{N}_{2} \mathrm{O}$ from day 7 to 19 , but when MTX was preceded by 3 days (7-10) $\mathrm{N}_{2} \mathrm{O}$, reduction of hepatosplenomegaly and leukocytosis was larger than with only continuous $\mathrm{N}_{2} \mathrm{O}$ (day 7-19); the latter combined with $2 \mathrm{mg} / \mathrm{kg}$ MTX i.p. at day 10 still further enforced the anti-leukemic effect. Doubling of the MTX dose to $4 \mathrm{mg} / \mathrm{kg}$ made it equivalent to continuous $\mathrm{N}_{2} \mathrm{O}$; when it was preceded by 3 days $\mathrm{N}_{2} \mathrm{O}$, a very strong leukemia regression was seen, whereas in combination with continuous $\mathrm{N}_{2} \mathrm{O}$ the rats died from toxic effects at day 12-14 without obvious leukemia. Reductions in peripheral promelocytes ran parallel with decreasing spleen weights as well as plasma cobalamin levels, which doubled in untreated animals and dropped to subnormal in the most effective combined treatments. $\mathrm{dU}$-suppression test values on leukemic spleen cells, 18 hours after MTX i.p. $0,5 \mathrm{mg} / \mathrm{kg}$, increased in parallel with previous exposure to $\mathrm{N}_{2} \mathrm{O}$ for 1,2 , or 3 days, whereas intracellular d-TTP decreased [25]. Surprisingly synergism did not occur when $\mathrm{N}_{2} \mathrm{O}$ was administered after MTX.

Another antifolate, 5-fluorouracil (FU), which competitively inhibits thymidylate synthase, has for long been a valuable ingredient in chemotherapy of especially breast and bowel carcinomas $[40,41]$, but has usually been regarded to be of little value in the treatment of leukemias. Application of FU in BNML rats showed that this anti-folate itself already has a striking anti-leukemic potency when evaluated on leukemia day 20 . A low dose of $3 \times 15 \mathrm{mg} / \mathrm{kg}$ FU i.p. on days 7, 12, and 17 was as effective as $\mathrm{N}_{2} \mathrm{O}$ on days $7-19$, and combination of the two was shown to be synergistic. After a single dose of $25 \mathrm{mg} / \mathrm{kg}$ FU i.p. on day 14 , liver and spleen weights had only slightly increased at sacrifice, and when preceded by 4 days inhalation of $\mathrm{N}_{2} \mathrm{O}$ these weights even remained normal with disappearance of leukemic cells in the peripheral blood. As with MTX, synergism was absent when $\mathrm{N}_{2} \mathrm{O}$ was inhaled after injection of FU. BNML rat survival, being $22.0 \pm 0.5$ days, increased to $34.3 \pm$
0.5 days with $25 \mathrm{mg} / \mathrm{kg}$ FU on day 14 and even to 40.2 \pm 1.5 days with additional $\mathrm{N}_{2} \mathrm{O}$ at days $10-14$. The anti-leukemic effect of FU was also mirrored by increasing dU suppression test values and decreasing intracellular folate levels $[26,29]$.

The studies in BNML rats in general indicate that $\mathrm{N}_{2} \mathrm{O}$ has a moderate anti-leukemic effect when breathed continuously. Its methyl-cobalamin inactivation in the rats has probably been maximal with continuous inhalation of $50 \% \mathrm{~N}_{2} \mathrm{O} / 50 \% \mathrm{O}_{2}$. In man the cytotoxic effect of $\mathrm{N}_{2} \mathrm{O}$ may be relatively stronger in view of the reported accidental and intended cytopenias [2-4]. Recently a dramatic reduction of hyper-leukocytosis during 4 days of $\mathrm{N}_{2} \mathrm{O}$ in a patient with chronic myelogenous leukemia was reported [42]. It is possible that the same antileukemic effect can be obtained with intermittent inhalation or with lower concentrations of $\mathrm{N}_{2} \mathrm{O}[43,44]$, which would make the application in clinical practice more acceptable. $\mathrm{N}_{2} \mathrm{O}$ inhalation seems to be an attractive alternative for, or an adjunct to, leukapheresis or high-dose hydroxycarbamide in the treatment of hyperleukocytosis. Its role in the treatment of acute leukemias has to be sought in the synergism with other anti-folates, as a basis on which cycloleucine, and especially MTX and FU, become effective in smaller and therefore probably less toxic dosages. In the BNML rats the ratio of effectiveness and toxicity of antifolates seems to become more favorable in combination with $\mathrm{N}_{2} \mathrm{O}$. Studies on MTX toxicity in normal rats are showing that the $L_{50}$ falls from $60 \mathrm{mg} / \mathrm{kg}$ to $10 \mathrm{mg} / \mathrm{kg}$ after exposure to $\mathrm{N}_{2} \mathrm{O}$ for 48 hours; 5 formyl-THF remains a good antidote, but methyl-THF is not, in agreement with the expected outcome [30]. The anti-leukemic property of FU in BNML rats is surprising in view of its impopularity in the treatment of human acute leukemias [31]. FU in combination with MTX is being used in chemotherapy of solid tumors and recently has been reported to induce complete remissions in some patients with refractory leukemia [45]. We have found that dU-suppression test values on bone marrow cells from 18 patients with acute leukemia change moderately after in vitro exposure to $\mathrm{N}_{2} \mathrm{O}$ but increase significantly with addition of cycloleucine, MTX, or FU, in concordance with the synergism observed in BNML rats [29]. This possibly predicts that combining anti-folates with $\mathrm{N}_{2} \mathrm{O}$ might render an attractive approach in the treatment of acute leukemias.

\section{REFERENCES}

l. Davy H: "Researches, Chemical and Philosophical, Chiefly Concerning Nitrous Oxide or Dephlogisticated Air, and Its Respiration.' London: J Johnson, 1800.

2. Lassen HCA, Henriksen E, Neukirch F, Kristensen HS: Treatment of tetanus. Severe bone marrow depression after prolonged nitrous-oxide anaesthesia. Lancet 1:527, 1956 
3. Lassen HCA, Kristensen HS: Remission in chronic myeloid leucaemia following prolonged exposure to nitrous oxide. Dan Med Bull 6:252, 1959.

4. Eastwood DW, Green CD, Lambdin MA, Gardner R: Effect of nitrous oxide on the white-cell count in leukemia. N Engl J Med 268:297. 1964.

5. Kieler J: The cytotoxic effect of nitrous oxide at different oxygen tensions. Acta Pharmacol Toxicol (Copenh) 13:301, 1957.

6. Green CD, Eastwood DW: Effects of nitrous oxide inhalation on hemopoiesis in rats. Anesthesiology 24:34l, 1963.

7. Fink BR: Carcinostatic action of nitrous oxide in mice. Anesthesiology 27:214, 1966.

8. Parbrook GD: Experimental studies into the effect of nitrous oxide on tumour cell growth. Br J Anaesth 39:549, 1967.

9. Banks RGS, Henderson RJ, Pratt JM: Reactions of gases in solution. Part III. Some reactions of nitrous oxide with transition-metal complexes. J Chem Soc (A) 12:2886, 1968.

10. Amess JAL, Burman JF, Rees GM, Nancekievill DG, Mollin DL: Megaloblastic haemopoiesis in patients receiving nitrous oxide. Lancet $2: 339,1978$.

11. Noronha JM, Silverman M: On folic acid, vitamin B12, methionine and formiminoglutamic acid metabolism. In Heinrich $\mathrm{HC}$ (ed): "Vitamin B 12 und Intrinsic Factor," 2. Europaisches Symposium. Stuttgart: Enke, 1962, p 728.

12. Herbert V, Zalusky R: Interrelationships of vitamin B 12 and folic acid metabolism: Folic acid clearance studies. J Clin Invest 41:1263, 1962.

13. Weir DG, Scott JM: Interrelationships of folates and cobalamins. In Lindebaum $J$ (ed): "Nutrition in Hematology." New York: Churchill Livingstone, 1983, p 121.

14. Schilling RF: Is nitrous oxide a dangerous anesthetic for vitamin B 12deficient subjects? JAMA 255:1605, 1986.

15. Layzer RB, Fishman RA, Schafer JA: Neuropathy following abuse of nitrous oxide. Neurology 28:504, 1978.

16. Scott JM, Dinn JJ, Wilson P, Weir DG: Pathogenesis of subacute combined degeneration: A result of methyl group deficiency. Lancet II:334, 1981

17. Peytremann R, Thorndike J, Beck WS: Studies on N5-methyltetrahydrofolate-homocysteine methyltransferase in normal and leukemic leukocytes. J Clin Invest 56:1293, 1975.

18. Kano Y, Sakamoto S, Hida K, Tsuboyama A, Takafu F: Vitamin B12-dependent methyltetrahydrofolate: Homocysteine methyltransferase activity in normal and leukemic human hematopoietic cells Clin Chim Acta 109:69, 1981

19. Kano Y, Sakamoto S, Hida K, Suda K, Takafu F: 5-Methyltetrahydrofolate-related enzymes and DNA polymerase-alpha in normal and malignant hematopoietic cells. Eur J Cancer Clin Oncol 19:945, 1983.

20. Corcino JJ, Zalusky R, Greenberg M, Herbert V: Coexistence of pernicious anaemia and chronic myeloid leukaemia: An experiment of nature involving vitamin Bl2 metabolism. Br J Haematol 20:511, 1971 .

21. Ahmann FR, Durie BGM: Acute myelogenous leukaemia modulated by $\mathrm{B} 12$ deficiency: A case with bone marrow blast cell corroboration. Вi J Haematol 58:91, 1984.

22. Huennekens FM, DiGirolamo PM, Fujii K, Jacobsen DW, Vitols KS: B12-dependent methionine synthetase as a potential target for cancer chemotherapy. In: Weber G (ed): "Advances in Enzyme Regulation." Oxford: Pergamon, vol 14, 1976, p 187.

23. Kroes ACM, Lindemans J, Hagenbeck A, Abels J: Nitrous oxide reduces growth of experimental rat leukemia. Leuk Res 8:441, 1984.

24. Kroes ACM, Lindemans J, Abels J: Synergistic growth inhibiting effect of nitrous oxide and cycloleucine in experimental rat leukemia. Br J Cancer 50:793, 1984

25. Kroes ACM, Lindemans J, Schoester M, Abels J: Enhanced thera- peutic effect of methotrexate in experimental rat leukemia after inactivation of cobalamin (vitamin B12) by nitrous oxide. Cancer Chemother Pharmacol 17:114, 1986

26. Kroes ACM, Ermens AAM, Lindemans J, Abels J: Effects of 5 fluoroucil treatment of rat leukemia with concomittant inactivation of cobalamin. Anticancer Res 6:737, 1986.

27. Kroes ACM, Ermens AAM, Lindemans J, Schoester M, Abels J: The reduction of intracellular polyamines by sequential inhibition of the synthesis of decarboxylated 5-adenosylmethionine: Effects on rat leukemia. Cancer Lett 41:295, 1988.

28. Ermens AAM, Vink N, Schoester M, van Lom K, Lindemans J, Abels $J$ : Nitrous oxide selectively reduces the proliferation of the malignant cells in experimental rat leukemia. Cancer Lett 45:123, 1989.

29. Ermens AAM, Kroes ACM, Schoester M, van Lom K, Lindemans J, Abels J: Effect of cobalamin inactivation on folate metabolism of leukemic cells. Leuk Res 12:905, 1988.

30. Ermens AAM, Schoester M, Spijkers LJM, Lindemans J, Abels J; Toxicity of methotrexate in rats pre-exposed to nitrous oxide. Cancer Res: 49:6337, 1989.

31. Ermens AAM, Kroes ACM, Lindemans J, Abels J: 5-Fluorouracil treatment of rat leukemia and a reappraisal of its application in human leukemia. Anticancer Res 6:797, 1986.

32. Hagenbeek A: Introduction of the BN myelocytic leukaemia. Leuk Res 1:85, 1977.

33. Van Bekkum DW, Hagenbeek A: Relevance of the BN leukemia as a model for human acute myeloid leukemia. Blood Cells 3:565, 1977.

34. Metz J, Kelly A, Swett VC, Waxman S, Herbert V: Deranged DNA synthesis by bone marrow from vitamin B 12-deficient humans. Br J Haematol 14:575, 1968.

35. Connors TA, Elson LA, Hadow A, Ross WCJ: The pharmacology and tumour growth inhibitory activity of l-aminocyclopentane-1-carboxylic acid and related compounds. Biochem Pharmacol 5:108, 1960.

36. Savlov ED, MacIntyre JM, Knight E, Wolter J: Comparison of doxorubicin with cycloleucine in the treatment of sarcomas. Cancer Treat $\operatorname{Rep} 3: 1,1961$.

37. Dindogru A, Leichman LP, Cummings G, Baker LH: Phase II study of high-dose intermittent cycloleucine in colorectal malignancies. Cancer Treat Rep 66:203, 1982.

38. Jolivet J, Cowan KH, Curt GA, Clendeninn NJ, Chabner BA: The pharmacology and clinical use of methotrexate. N Engl J Med 309: $1094,1983$.

39. Goldhirsch A, Gelber RD, Tattersall MNH, Rudenstam CM, Cavalli F: Methotrexate/nitrous oxide toxic interaction in perioperative chemotherapy for early breast cancer. Lancet II:151, 1987.

40. Heidelberger C, Chaudhuri NK, Danneberg P: Fluorinated pyrimidines, a new class of tumour-inhibitory compounds. Nature 179: $663,1957$.

41. Valeriote F, Santelli G: 5-Fluorouracil. Pharmacol Ther 24, 1984.

42. Ikeda K, Aosaki T, Furukawa Y, Ohta M, Kano Y, Tsuboyama A, Sakamoto S, Miura Y, Sakuraya K, Fuke N, Kubota T: Antileukemic effect of nitrous oxide in a patient with chronic myelogenous leukemia. Am J Hematol 30:114, 1989.

43. Kondo H, Osborne ML, Kolhouse JF, Binder MJ, Podell ER, Ulley CS. Abrams RS, Allen RH: Nitrous oxide has deleterious effects on cobalamin metabolism and causes decreases in activities of both mammalian cobalamin-dependent enzymes in rats. J Clin Invest 67:1270, 1981.

44. Nunn JF, Sharer NM, Gorcheim A, Jones JA, Wickramasinghe SN: Megaloblastic haemopoiesis after multiple short-term exposures to nitrous oxide. Lancet I:1379, 1982.

45. Linker CA, Ries CA, Saks CR, Cadman EC: Treatment of refractory acute leukemia with sequential methotrexate and 5-fluorouracil Blood 64(Suppl 1):169", 1984 